\title{
An Analysis of Long Run Determinants on Domestic Private Investment in Côte d'Ivoire
}

\author{
Nahousse Diabate \\ UFR Sciences Economique et de Développement, Université Alassane \\ Ouattara (UAO) Bouaké, Côte d'Ivoire
}

doi: 10.19044/esj.2016.v12n28p240 URL:http://dx.doi.org/10.19044/esj.2016.v12n28p240

\begin{abstract}
This study aims to model the long run determinants of domestic private investment in Côte d'Ivoire. Advanced econometric technique of Auto-Regressive Distributed Lag (ARDL) bounds testing approach is employed. Data from our study covers the period from 1970 to 2012. The results indicate that public investment, foreign direct investment, trade are the major determinants of short run and long run domestic private investment in Côte d'Ivoire while the real GDP growth rate and the interest rate are statistically insignificant. Thus, efforts should be geared to the development of necessary public investments in infrastructure such as supply constant electricity, good highways and elimination of the negative effects of external shocks engendered by the investment uncertainty and the deterioration of terms of trade.
\end{abstract}

Keywords: domestic private investment, cointegration

\section{Introduction}

Private investment has positive effects on economic growth (Dehn 2000) and employment (Jayaraman and Singh, 2007). As the result of the recent global financial crises the world has experienced, political and economical Leaders are to consider alternative approaches to achieve a sustainable growth. Thus, the development of domestic private investment was integrated as a solution (Ajide and Lawanson, 2012).

The potential bound to Ivorian private domestic investments have not been well exploited in spite of all the reforms introduced by the country; what motivated this study.

Indeed, available statistics show that the ratio of private investment to GDP in Côte d'Ivoire is be unsatisfactory $(16.01 \% \text { of GDP })^{6}$. Thus, it becomes essential to go deeply through the determinants of domestic private

${ }^{6}$ World Bank 
investment in Côte d'Ivoire. This will not only make out now domestic private investment is stimulated in the country, but also guide for policy making as empirical reference.

Several studies on the determinants of investment were realized since the pioneering work of Keynes (1936) among which the approaches of the accelerator (Goodwin, 1951; Chenery 1952; Lucas, 1967; Treadway, 1974; Jorgensen, 1971) and Tobin's q (Tobin, 1969). However, the theories or approaches mentioned above, the flexible accelerator theory is the most popular and the most used to analyse the behavior of investment in the least developed countries and especially in sub-Saharan Africa (SSA). For this reason, studies on the behavior of private investment in SSA simply focus on tests of assumptions that explain variations in private investment in these economies (Mutenyo and al. 2010).

Many studies on determinants of private investment has been achieved in the developing world and Sub-Saharan Africa in particular. This is the case of Waheed (2015) in Pakistan, Nainggolan, Ramli, Daulay and Rujiman (2015) in Indonesia, Ambaye, and Berhanu Abera (2014) in Ethiopia, Hamuda, Suliková, Gazda and Horváth (2013) in Tunisia, Molapo and Damane (2014) in Lesotho, Ajide and Lawanson (2012) in Nigeria.

Literature on investment is huge both in the developed and developing countries. However, few studies exist about specific country experiences in the sub-Saharan region. In our knowledge, in Côte d'Ivoire for instance, there is no study on investment that has neither explored the relationship between domestic private investment and its determinants nor used the approach of Autoregressive Distributed Lag (ARDL) defined by Pesaran et al. (2001). Indeed, this approach takes into account the shortcomings of the VAR model such as the requirement of integration of the same series order. But in most macroeconomic series this condition is not verified (Nelson and Plosser, 1982). Regarding the nature of our data and our hypotheses, we will use this approach. Finally, this study is important since it covers the period from 1970 to 2012 making the results more relevant.

Firstly, it's question of estimating the function of domestic private investment in Côte d'Ivoire. And secondly, to provide the authorities with an additional tool of decision.

To achieve these objectives, our reflection is organized into four essential sections: section 2 presents the data and the methodology. Section 3 deals with the empirical results and their economic interpretation. Section 4 sets out the implications of economical policies.

\section{Data and methodology}

The annual data used cover the period from 1970 to 2012 and are about Côte d'Ivoire. The choice of this period results from the availability of 
data on the concerned variables. Data related to trade, foreign direct investment and the rate of growth of gross domestic product, domestic private investment and public investment are collected from the database of Africa Development Indicators (ADI) of the World Bank. All these variables are expressed in rate. As for the real interest rate (lender rate), we used the statistics of the Central Bank of West African States (BCEAO). The study employs autoregressive distributed lag (ARDL) bounds testing approach to cointegration developed by Pesaran and Shin (1999) and later extended by Pesaran et al. (2001) to examine the long-run and causal relationship between trade, foreign direct investment, rate of growth of gross domestic product, domestic private investment, real interest rate (lender rate) and public investment. The ARDL bounds test approach to cointegration has several advantages that have recently made it popular and preferred to other traditional cointegration techniques such as Engel and Granger (1987) and Johansen and Juselius (1990). The ARDL approach to cointegration performs better in small samples such as in our case. Unlike Johansen's cointegration technique that requires that variables under consideration be integrated of the same order the ARDL allows the undertaking of cointegration analysis regardless of whether the variables are integrated of order zero $[\mathrm{I}(0)]$, or order one $[\mathrm{I}(1)]$. Furthermore, since the ARDL method can identify dependent and explanatory variables, it gives estimates that are consistent because it avoids problems related to endogeneity.

The long-term equilibrium relationship between domestic private investment and its determinants (the variables better capture the behavior of the domestic private investment variables such as Keynesian, neoclassical, neo-liberal and uncertainty) may be expressed as follows:

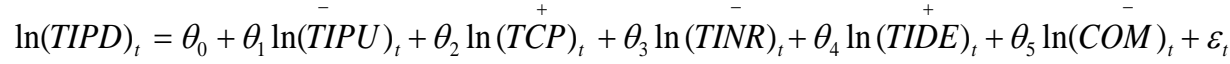

TIPD: domestic private investment rates; TIPU: public investment rate; TCP: GDP growth rate; TINR: real interest rates; TIDE: direct foreign investment rate; COM: the ratio of the value of trade on GDP, In is nipperien logarithm. For that purpose, we adopt the model developed by Ajide and Lawanson $(2012)^{7}$. Our ARDL model is then presented as follows:

\footnotetext{
${ }^{7}$ Because the WAEMU countries follow a common monetary policy, nominal interest rates are identical and therefore the real interest rates are correlated with the inflation rate. In fact, inflation reduces the real rate of interest, which has negative effects on the credit volume, the level of investment and economic activity (24) (Huybens and Smith, 1999). For this reason we do not take into account inflation and the rate of loans to the private sector.
} 
$\Delta \ln (T I P D)_{t}=\beta_{0}+\sum_{i=1}^{n} \beta_{1 i} \Delta \ln (T I P D)_{t-i}+\sum_{i=0}^{n} \beta_{2 i} \Delta \ln (T I P U)_{t-i}+\sum_{i=0}^{n} \beta_{3 i} \Delta \ln (T C P)_{t-i}+\sum_{i=0}^{n} \beta_{5 i} \Delta T I N R_{t-1}+\sum_{i=0}^{n} \beta_{6 i} \Delta \ln (T I D E)_{t-i}$

$+\sum_{i=0}^{n} \beta_{7 i} \Delta \ln (C O M)_{t-i}+\alpha_{1} \ln (\text { TIPD })_{t-1}+\alpha_{2} \ln (\text { TIPU })_{t-1}+\alpha_{3} \ln (T C P)_{t-1}+\alpha_{4} \operatorname{TINR}_{t-1}+\alpha_{5} \ln (\text { TIDE })_{t-1}+\alpha_{6} \ln (C O M)_{t-1}+\varepsilon_{t}$

In these equations, $\Delta$ denotes the first difference operator, $\varepsilon_{t}$ stand for the error term is white noise, $\mathrm{n}$ is the optimal delay, $\beta_{0}$ is the constant. The features that meet $\alpha_{1}$ to $\alpha_{6}$ characterize long run balance between the variables while the coefficients $\beta_{1}$ to $\beta_{7}$ represent short period of the balance between the studied series. $\mathrm{P}$ The delay is determined by AIC and SC information criteria, it corresponds to the delay that minimizes these criteria. To test for the absence of cointegration, Pesaran and al. (2001) conducted the following test:

$H_{0}=\alpha_{1}=\alpha_{2}=\alpha_{3}=\alpha_{4}=\alpha_{5}=\alpha_{6}=0 \quad$ (No cointegration); Against the alternative hypothesis

H1: (cointegration in) using Fisher tests (or Wald) in a non-standard law (Motabelli and Ghorbani, 2009). The resort to Wald test or to the Fstatistic allows to test the significance of the variables delay by taking into account the constraint of an error correction model (ECM). The asymptotic distribution of this test (obviously from Fisher) is not standardized under the null hypothesis of no cointegration between variables. Therefore, the estimated value of this statistic must be compared to the critical values established by Pesaran and al (2001) procedure in order to validate or refute the assumptions. Two sets of critical values, lower and upper bound values, for large sample data sets are developed by Pesaran et al. (2001). It is important to note that the critical values based on large sample size deviates significantly from that of small sample size. Narayan (2005) reports small sample critical values. The upper bound critical values are estimated assuming that all variables in the ARDL model are integrated of order one [I(1)], and the lower bound critical values are computed assuming that the variables are integrated of order zero [I(0)]. At any chosen significance level if the computed F-statistic falls between the lower and upper bound critical values, the decision about cointegration between the underlying variables is inconclusive. However, if the computed F statistic exceeds the upper bound critical value the null hypothesis is rejected and the decision is that the underlying variables are cointegrated. On the other hand if the computed Fstatistic is less than the lower bound critical value the null hypothesis is not rejected and it is concluded that the variables are not cointegrated. The critical value has lower bound $\left(F_{L}\right)$ and upper bound $\left(F_{U}\right)$. If $\hat{F} \prec F_{L}$ no cointegration relation exists and when $\hat{F} \succ F_{U}$ a cointegration relation exists. 
However, when $F_{L} \prec \hat{F} \prec F_{U}$, inference remains inconclusive under such circumstance, a knowledge of the order of integration of the underlying variables is needed to proceed further. It's important that test must be made considering each variable as endogenous. It is important to test the exogenous nature of each variable in the equation 2. Given that, we have 6 variables in our equation, we must verify the weak exogeneity condition of regressors. In other words, firstly, estimate equation 2 and test $H_{0}=\alpha_{1}=\alpha_{2}=\alpha_{3}=\alpha_{4}=\alpha_{5}=\alpha_{6}=0 \quad$ secondly, estimate equation 2 with dependent variable $\Delta \ln \left(\right.$ TIPU) and test $H_{0}=\alpha_{1}=\alpha_{2}=\alpha_{3}=\alpha_{4}=\alpha_{5}=\alpha_{6}=0$ ; thirdly, estimate equation 2 with dependent variable $\Delta \ln (\mathrm{TCP})$; and so on. If null hypothesis of no cointegration is accepted for $\ln (\mathrm{TIPU}), \ln (\mathrm{TCP})$, $\ln (\mathrm{TIDE}), \mathrm{TINR}, \ln (\mathrm{COM})$ and rejected to $\ln (\mathrm{TIPD})$ then ARDL approach will be valid. On the contrary, if there are more than one cointegration relation, thus you must use a VECM approach. If null hypothesis of no cointegration is accepted for $\ln (\mathrm{TIPU}), \ln (\mathrm{TCP}), \ln (\mathrm{TIDE}), \mathrm{TINR}, \ln (\mathrm{COM})$ and rejected to $\ln (\mathrm{TIPD})$, we will develop an error correction model (ECM) as follows:

$$
\begin{aligned}
\Delta \ln (T I P D)_{t} & =\beta_{0}+\sum_{i=1}^{n} \beta_{1 i} \Delta \ln (T I P D)_{t-i}+\sum_{i=0}^{n} \beta_{2 i} \Delta \ln (T I P U)_{t-i}+\sum_{i=0}^{n} \beta_{3 i} \Delta \ln (T C P)_{t-i}+\sum_{i=0}^{n} \beta_{4 i} \Delta \operatorname{TINR}_{t-1}+\sum_{i=0}^{n} \beta_{6 i} \Delta \ln (T I D E)_{t-i} \\
& +\sum_{i=0}^{n} \beta_{7 i} \Delta \ln (C O M)_{t-i}+\lambda E C_{t-1}+\varepsilon_{t}
\end{aligned}
$$

Where $\lambda$ is the speed of parameter adjustment and EC stands for the residues obtained from the estimation of the cointegrated equation model.

\section{Econometric results}

Several tests are needed to verify the assumptions under which the model estimation can be robust. The tests that we present are unit roots test, co-integration test and diagnostic tests.

\section{Unit Root Test Results}

This first requirement for time series econometrics analysis is to subject each time series to stationary or unit root tests. The two methods employed for this test were Augmented Dickey-Fuller (ADF) and Kwiatkowski, Phillips, Schmidt, Shin (KPSS) tests. The KPSS test hypothesizes stationarity as null hypothesis while the ADF test poses the hypothesis of the presence of unit root as null hypothesis. Thus, for the ADF test, if the calculated statistic is less than the critical value, we will reject the null hypothesis of unit root, the serie is stationary. In the case of KPSS test the null hypothesis of stationarity is rejected if the test statistic is greater than the critical value. The results of these tests are presented in Table 1. 
According to the results two out of five variables are I(0) (LCOM, TCP) and all other variables are I (1) (LTIPD, LTIPU, TIDE, TINR).

Table 1: Results of the stationarity tests

\begin{tabular}{cccc|ccc}
\hline \hline & \multicolumn{3}{c}{ in level } & \multicolumn{3}{c}{ In first differences } \\
& ADF & PP & KPSS & ADF & PP & KPSS \\
\hline \hline LCOM & $-3.378654^{*}$ & $-3.378654^{*}$ & 0.159396 & $-7.906827^{*}$ & $-8.412746^{*}$ & 0.111092 \\
& $(-2.929734)$ & $(-2.929734)$ & $(0.463000)$ & $(-2.931404)$ & $(-2.931404)$ & $(0.463000)$ \\
LTIPD & -2.304758 & -2.173955 & $0.759544^{*}$ & $-7.541298^{*}$ & $-11.11076^{*}$ & 0.202744 \\
& $(-2.929734)$ & $(-2.929734)$ & $(0.463000)$ & $(-2.931404)$ & $(-2.931404)$ & $(0.463000)$ \\
LTIPU & -2.035088 & -2.338873 & $0.789767^{*}$ & $-8.586354^{*}$ & $-28.30178^{*}$ & 0.243208 \\
& $(-2.931404)$ & -2.929734 & $(0.463000)$ & $(-2.933158)$ & $(-2.931404)$ & $(0.463000)$ \\
TCP & $-8.599264 *$ & $-8.748608^{*}$ & 0.290880 & $-6.189926^{*}$ & $-52.16330 *$ & 0.148414 \\
& $(-2.929734)$ & $(-2.929734)$ & $(0.463000)$ & $(-2.938987)$ & -2.931404 & $(0.463000)$ \\
TIDE & -2.015193 & $-3.767876 *$ & $0.570338^{*}$ & $-11.52945^{*}$ & $-15.54154^{*}$ & 0.070254 \\
& $(-2.931404)$ & $(-2.929734)$ & $(0.463000)$ & $(-2.931404)$ & $(-2.931404)$ & $(0.463000)$ \\
TINR & $-4.990420^{*}$ & $-5.020861 *$ & $0.584719^{*}$ & $-10.663313^{*}$ & $-20.39022 *$ & 0.346162 \\
& $(-2.929734)$ & $(-2.929734)$ & $(0.463000)$ & $(-2.931404)$ & $(-2.931402)$ & $(0.463000)$ \\
\hline \hline
\end{tabular}

Note: * indicates rejection of the null hypothesis at $5 \%$; the value on bracket is critical value at $5 \%$

\section{Cointegration test}

After the stationarity tests, we proceed to the cointegration test. Table 2 presents cointegration test results. It emerges that the variables TCP, TIPU, TCP, TIDE, TINR, COM can be considered as weakly exogenous for the long term coefficients at $5 \%$ level. The only one long-term relationship is the one that we identified (the dependent variable is a domestic private investment). Indeed, the computed F-statistic (10.786) is higher than the upper critical value at $1 \%, 5 \%$ and $10 \%$ as indicated in table 2 . Following the establishment of long-run co-integration relationship among the variables, the long-run and short-run dynamic parameters for the variables were obtained.

Table 2: Bounds test for cointegration analysis

\begin{tabular}{|c|c|c|c|c|c|c|c|c|}
\hline \multirow{2}{*}{$\begin{array}{c}\text { Depende } \\
\text { nt } \\
\text { variable }\end{array}$} & \multirow{2}{*}{$\begin{array}{c}\text { F- } \\
\text { Statist } \\
\text { ic }\end{array}$} & \multicolumn{2}{|c|}{$\begin{array}{c}\mathrm{CV} \text { at } 10 \% \\
\mathrm{~K}=5\end{array}$} & \multicolumn{2}{|c|}{$\begin{array}{c}\mathrm{CV} \text { at } 5 \% \\
\mathrm{~K}=5\end{array}$} & \multicolumn{2}{|c|}{$\begin{array}{c}\mathrm{CV} \text { at } 1 \% \\
\mathrm{~K}=5\end{array}$} & \multirow{2}{*}{$\begin{array}{c}\text { Remar } \\
\text { ks }\end{array}$} \\
\hline & & $\mathrm{I}(0)$ & $\mathrm{I}(1)$ & $\mathrm{I}(0)$ & $\mathrm{I}(1)$ & $\mathrm{I}(0)$ & $\mathrm{I}(1)$ & \\
\hline $\begin{array}{l}\Delta \ln (\mathrm{TIP} \\
\mathrm{D})\end{array}$ & $\begin{array}{c}10.78 \\
6\end{array}$ & $\begin{array}{c}\mathrm{T}_{1}=2.3 \\
06 \\
\mathrm{~T}_{2}=2.2 \\
76\end{array}$ & $\begin{array}{c}\mathrm{T}_{1}=3.3 \\
53 \\
\mathrm{~T}_{2}=3.2 \\
97\end{array}$ & $\begin{array}{c}\mathrm{T}_{1}=2.7 \\
34 \\
\mathrm{~T}_{2}=2.6 \\
94\end{array}$ & $\begin{array}{c}\mathrm{T}_{1}=3.9 \\
20 \\
\mathrm{~T}_{2}=3.8 \\
29\end{array}$ & $\begin{array}{c}\mathrm{T}_{1}=3.6 \\
57 \\
\mathrm{~T}_{2}=5.2 \\
56\end{array}$ & $\begin{array}{c}\mathrm{T}_{1}=3.6 \\
74 \\
\mathrm{~T}_{2}=5.0 \\
19\end{array}$ & Yes \\
\hline $\begin{array}{c}\Delta \ln (\mathrm{TCP} \\
)\end{array}$ & $\begin{array}{c}- \\
2.845 \\
6\end{array}$ & $\begin{array}{c}\mathrm{T}_{1}=2.3 \\
06 \\
\mathrm{~T}_{2}=2.2 \\
76\end{array}$ & $\begin{array}{c}\mathrm{T}_{1}=3.3 \\
53 \\
\mathrm{~T}_{2}=3.2 \\
97\end{array}$ & $\begin{array}{c}\mathrm{T}_{1}=2.7 \\
34 \\
\mathrm{~T}_{2}=2.6 \\
94\end{array}$ & $\begin{array}{c}\mathrm{T}_{1}=3.9 \\
20 \\
\mathrm{~T}_{2}=3.8 \\
29\end{array}$ & $\begin{array}{c}\mathrm{T}_{1}=3.6 \\
57 \\
\mathrm{~T}_{2}=5.2 \\
56\end{array}$ & $\begin{array}{c}\mathrm{T}_{1}=3.6 \\
74 \\
\mathrm{~T}_{2}=5.0 \\
19\end{array}$ & No \\
\hline $\ln (\mathrm{TIPU})$ & $\begin{array}{c}- \\
2.227 \\
1 \\
\end{array}$ & $\begin{array}{c}\mathrm{T}_{1}=2.3 \\
06 \\
\mathrm{~T}_{2}=2.2\end{array}$ & $\begin{aligned} & \mathrm{T}_{1}=3.3 \\
& 53 \\
& \mathrm{~T}_{2}=3.2\end{aligned}$ & $\begin{array}{c}\mathrm{T}_{1}=2.7 \\
34 \\
\mathrm{~T}_{2}=2.6\end{array}$ & $\begin{array}{c}\mathrm{T}_{1}=3.9 \\
20 \\
\mathrm{~T}_{2}=3.8\end{array}$ & $\begin{array}{c}\mathrm{T}_{1}=3.6 \\
57 \\
\mathrm{~T}_{2}=5.2\end{array}$ & $\begin{array}{c}\mathrm{T}_{1}=3.6 \\
74 \\
\mathrm{~T}_{2}=5.0\end{array}$ & No \\
\hline
\end{tabular}




\begin{tabular}{|c|c|c|c|c|c|c|c|c|}
\hline & & 76 & 97 & 94 & 29 & 56 & 19 & \\
\hline & & $\mathrm{T}_{1}=2.3$ & $\mathrm{~T}_{1}=3.3$ & $\mathrm{~T}_{1}=2.7$ & $\mathrm{~T}_{1}=3.9$ & $\mathrm{~T}_{1}=3.6$ & $\mathrm{~T}_{1}=3.6$ & \\
$\ln (\mathrm{TIDE}$ & 1.745 & 06 & 53 & 34 & 20 & 57 & 74 & No \\
) & 3 & $\mathrm{~T}_{2}=2.2$ & $\mathrm{~T}_{2}=3.2$ & $\mathrm{~T}_{2}=2.6$ & $\mathrm{~T}_{2}=3.8$ & $\mathrm{~T}_{2}=5.2$ & $\mathrm{~T}_{2}=5.0$ & \\
& & 76 & 97 & 94 & 29 & 56 & 19 & \\
\hline & & $\mathrm{T}_{1}=2.3$ & $\mathrm{~T}_{1}=3.3$ & $\mathrm{~T}_{1}=2.7$ & $\mathrm{~T}_{1}=3.9$ & $\mathrm{~T}_{1}=3.6$ & $\mathrm{~T}_{1}=3.6$ & \\
$\ln (\mathrm{COM}$ & 2.204 & 06 & 53 & 34 & 20 & 57 & 74 & No \\
) & 3 & $\mathrm{~T}_{2}=2.2$ & $\mathrm{~T}_{2}=3.2$ & $\mathrm{~T}_{2}=2.6$ & $\mathrm{~T}_{2}=3.8$ & $\mathrm{~T}_{2}=5.2$ & $\mathrm{~T}_{2}=5.0$ & \\
& & 76 & 97 & 94 & 29 & 56 & 19 & \\
\hline & & $\mathrm{T}_{1}=2.3$ & $\mathrm{~T}_{1}=3.3$ & $\mathrm{~T}_{1}=2.7$ & $\mathrm{~T}_{1}=3.9$ & $\mathrm{~T}_{1}=3.6$ & $\mathrm{~T}_{1}=3.6$ & \\
TINR & 1.982 & 06 & 53 & 34 & 20 & 57 & 74 & \multirow{2}{*}{ No } \\
& 2 & $\mathrm{~T}_{2}=2.2$ & $\mathrm{~T}_{2}=3.2$ & $\mathrm{~T}_{2}=2.6$ & $\mathrm{~T}_{2}=3.8$ & $\mathrm{~T}_{2}=5.2$ & $\mathrm{~T}_{2}=5.0$ & \\
& & 76 & 97 & 94 & 29 & 56 & 19 & \\
\hline
\end{tabular}

Note: Critical values are extracted from Narayan (2005); Case II: restricted intercept and no trend; $\mathrm{T}_{1}=40$ and $\mathrm{T}_{2}=45$ respectively.

\section{Result of the estimate by ARDL $(1,4,0,2,1,0)$}

The determinants best explain domestic investment in Côte d'Ivoire (adjusted R2 $=0.638$ ). The coefficient associated with the restoring force is negative and statistically significant at $1 \%$ level (-0.2552271). The error correction representation is then validated. The results of long run and short run are presented in Table 3.

Table 3: Long run and short run coefficients of Domestic Private Investment Determinants

\begin{tabular}{|c|c|c|c|}
\hline \multicolumn{4}{|c|}{ ARDL $(1,4,0,2,1,0)$ selected based on AIC } \\
\hline \multicolumn{4}{|c|}{ Estimated short run dynamic model } \\
\hline Independent variables & Elasticity & Standard err & T-Ratios \\
\hline Constant & 0,0305632 & 0,8672234 & $4.29 * * *$ \\
\hline$\Delta(\mathrm{Ltipu})$ & $-0,2433154$ & 0,2324755 & $-3.11^{* *}$ \\
\hline$\Delta($ Ltcp $)$ & $-0,0037554$ & $0,0,0848877$ & -1.14 \\
\hline$\Delta($ Ltide $)$ & 0,3804312 & 0,3392154 & $3.83 * *$ \\
\hline$\Delta($ Lcom $)$ & 0,3323644 & 0,2143943 & $2.55^{* *}$ \\
\hline$\Delta$ (t)inr) & 0,0004196 & 0,0049356 & 1.04 \\
\hline ECM(-1) & -0,2552271 & 0,1294827 & $-5.97 * * *$ \\
\hline \multicolumn{4}{|c|}{ Long run estimates of ARDL model } \\
\hline Constant & 0,11974904 & 0,7377407 & $2,671^{* *}$ \\
\hline Ltipu & 1,13130737 & 0,2324755 & $3.26^{* * *}$ \\
\hline Ltcp & $-0,01471395$ & 0,0848877 & $-2.56^{* *}$ \\
\hline Ltide & 1,01760589 & 0,2394689 & $\overline{-2.38^{* *}}$ \\
\hline Lcom & 0,60216019 & 0,2320701 & $3.20^{* * *}$ \\
\hline Tinr & 0,00164403 & 0,0049356 & $1,96 *$ \\
\hline \multicolumn{2}{|c|}{$\begin{array}{l}\text { R-squared } \quad=0,750 \\
\text { Adj R-squared }=0,638\end{array}$} & \multicolumn{2}{|l|}{$\begin{array}{l}\mathrm{AIC}=-2,881 \\
\mathrm{SBC}=-2,390\end{array}$} \\
\hline \multicolumn{2}{|c|}{$F(13, \quad 25)=6.3750$} & \multicolumn{2}{|c|}{$\mathrm{DW}=2.15232$} \\
\hline
\end{tabular}

Notes: (i) $* * *(* *) *$ indicate significant at the $1 \%, 5 \%$ and $10 \%$ respectively. 


\section{Diagnostic tests}

After the existence of a long run relationship between the variables in the model has been proved, we proceed to the estimation of long run model and short run of our model by using Bayesian information criteria of Schwarz or Akaike. It is now necessary to consider the relevance of our results through the diagnostic tests. The normality, the heteroskedasticity, the absence of self-correlation, structural stability of coefficients and the error's specification are all tested to validate our model. The results of this diagnostic tests show that the model residuals prove all hypotheses of linear model.

Table 4: Diagnostic Statistics

\begin{tabular}{c|c|c}
\hline \hline Test & Chi2 & Prob > chi2 \\
\hline \hline Normality Test & 0.693 & 0.431 \\
\hline \hline Heteroskedasticity (ARDL) & 0,263 & 0,6080 \\
\hline \hline Breusch Godfrey LM test & 0,717 & 0,3971 \\
\hline \hline Breusch-Pagan & 2,23 & 0,1358 \\
\hline \hline Ramsey RESET & 0,53 & 0,6638 \\
\hline \hline
\end{tabular}

Finally, the structural stability of long run and short run relations for the entire period examined by the accumulated sum (CUSUM) (Figure 1).

Figure 1: CUSM test result

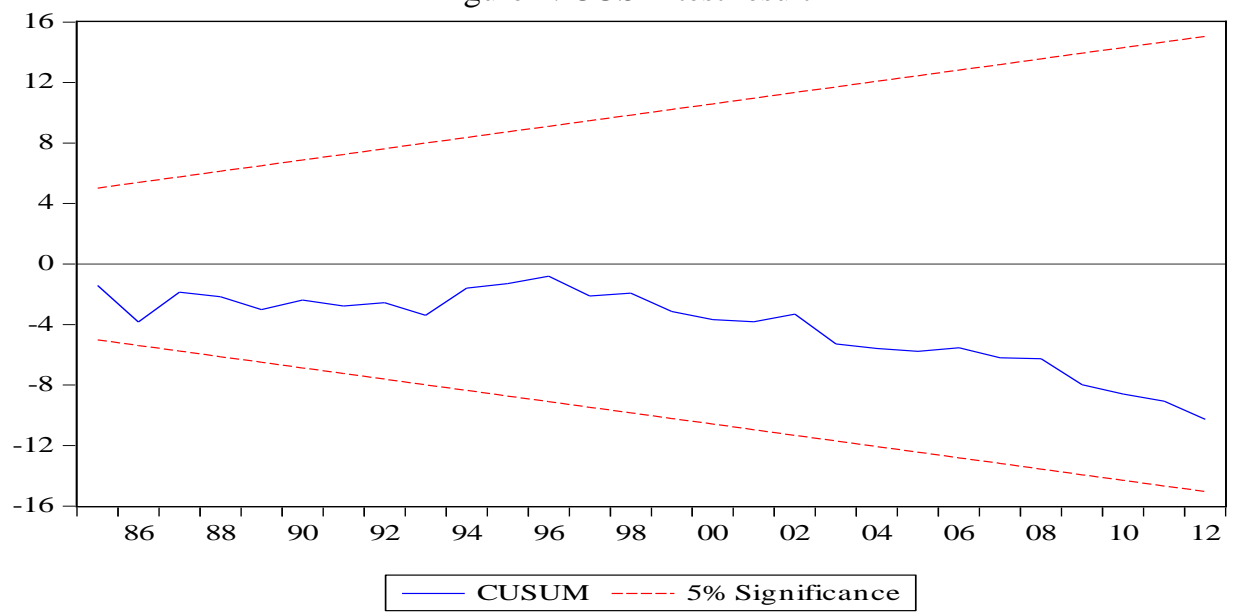

The curve of the CUSUM (in blue) does not exceed the confidence intervals (red color). The models used in the study appear to be correct and robust to explain the short run and long run relationships between domestic private investment and its determinants.

Contrary to our assumptions, the interest rate has a positive but nonsignificance coefficient on domestic private investment in Côte d'Ivoire both short run and long run. The not significant is explained by the fact that most investment activities are funded by banks from abroad. In fact, Ivorian banks 
finance very few medium and long term credits. Moreover, because of inflexible funding mechanisms in the "zone franc", local investors have little access to credit. This result is consistent with that found by Touna and al. (2002) and Demetriades and Devereux (1992). Conversely, they take an opposite view to those of Ajide, Lawanson (2012) and Ramli, Daulay, Rujiman (2015). Finally, on a theoretical level this result represents an empirical challenge to the neoclassical theory of interest rate.

Public investments have an significant negative impact on domestic private investment $(-0.2433154)$ in the short run while over the long run they positively influence the domestic private investment in Côte d'Ivoire (1.13130737) to $5 \%$. Public investment therefore has a domino effect on domestic private investment in Côte d'Ivoire, in the long run. Thus, even if the state is heavily involved in investment activities in the country, the component related to basic infrastructure (communication, transport, energy, health, education, etc.) was the most predominant. Note that according Blejer and Kahn (1984), the Economic and Social investment is complementary to private investment. This result is consistent with Greene and Villanueva (1991) and Ajide and Lawanson (2012).

Foreign direct investment has positive and significant effect in the short run (0.3804312) and long term (1.01760589) on domestic private investment to $5 \%$ in Côte d'Ivoire. These results show that foreign direct investment (FDI) use local businesses to subcontract certain activities. Furthermore, local investors in Côte d'Ivoire benefit from technology transfers necessary for the growth and expansion on the part of IDE. Empirically, this result is opposed to those obtained by Ajide, Lawanson (2012) and Mohsen (2015).

Trade, with coefficients (0.3323644) and (0.60216019) Short run and long run respectively, reveal a positive effect on domestic private investment in Cote d'Ivoire. Thus, trade improves the current account balance of Côte d'Ivoire. Moreover, this result emphasizes the importance of economic openness and economic integration for the Ivorian economy. At the empirical level, this result is compliant to the work of Ajide (2013).

As opposed to economic theory, the GDP growth rate per capita does not affect the level of domestic private investment in the short run. In the long run, it negatively and significantly influence at 5\% level of domestic private investment in Cote d'Ivoire. This point out the benefits of growth in Côte d'Ivoire does not profit to local investors revealing that Ivorian growth is not inclusive. In theoretical terms, this result questions challenges the accelerator effect of neoclassical economic growth in Côte d'Ivoire. It this is opposed to those of Idar-Naa, Ayentimi and Frimpong (2012) and Ramli, Daulay and Rujiman (2015). 


\section{Conclusion and recommandations}

The major objective of this study is to highlight the long run determinants of domestic private investment in Cote d'Ivoire. The recent global financial crisis has caused a reduction in flows of foreign direct investment (FDI) and portfolio investment towards developing countries. It's what explained the renewed interest in modeling the determinant of domestic private investment in Côte d'Ivoire.

To achieve the set objective, we have used annual data covering the period from 1970 to 2012. The econometric technique Auto-Regressive Distributed Lag (ARDL) developed by Pesaran and al. (2001) was used. The results indicated that public investment, foreign direct investment, trade are the major determinants of short run and long run domestic private investment in Cote d'Ivoire while the real GDP growth rate and rates interest are statistically insignificant.

Thus, efforts should be geared to the development of necessary public investments in infrastructure such as supply constant electricity, good highways, better health care delivery system, etc. This will provide a good environment to the development of domestic private investment namely for the small and medium companies. Second, a focus must be on collaboration between foreign investors and local entrepreneurs in the choice inbound FDI.

In addition, the State must promote openness through sub-regional integration and regional while reducing the negative effects of external shocks generated by the uncertainty of the investment and the deterioration of terms of trade. Finally, considering that most variables are significant in the long run, it's important that policy development can outlive from to government change.

\section{References:}

1. Ajide, K, B. (2013): The Role of Governance on Private Investment in Nigeria: A Preliminary Analysis, Central Bank of Nigeria Economic and Financial Review, 51: 93-119.

2. Ajide, K, B. and Lawanson, O. (2012): Modelling the Long Run Determinants of Domestic Private Investment in Nigeria, Asian Social Science, 8: 139-152.

3. Ambaye, G., Berhanu, T. and Abera, G. (2014): Modeling the Determinants of Domestic Private Investment in Ethiopia, Agris online Papers in Economics and Informatics, 5: 13-23

4. Blejer, M, I. and Khan, M, S. (1984): Government Policy and Private Investment in Developing Countries. Staff Papers (International Monetary Fund), 31: 379-403.

5. Chenery, B, H. ( 1952): Overcapacity and the Acceleration Principle., Econometrica, 20: 1-28. 
6. Dehn, J. (2000): Private Investment in Developing Countries:The Effects of Commodity Shocks and Uncertainty. Oxford, WPS. 11.

7. Ghorbani, M and Motallebi, M. (2009): Application Pesaran and Shin Method for Estimating Irans` Import Demand Function, Journal of Applied Sciences, 9: 1175-1179.

8. Goodwin, R, M. (1951): The Nonlinear Accelerator and the Persistence of Business Cycles, Econometrica, 19: 1-17.

9. Greene, J. and Villanueva, D. (1991): Private Investment in Developing Countries: An Empirical Analysis, Staff Papers (International Monetary Fund), 31: 33-58.

10. Hamuda, A, M., Suliková, V., Gazda, V, and Horváth, D. (2013): ARDL investment model of Tunisia, Theoretical and Applied Economics, 20: 57-68.

11. Jayaraman, T, K. and Baljeet S. (2007): Foreign direct investment and employment creation in Pacific Island countries: an empirical study of Fiji. Asia-Pacific Research and Training Network on Trade Working Paper Series, 35: 1-15.

12. Jorgensen D, W. (1971): Econometric Studies of Investment Behavior: A Survey, Journal of Economic Literature, 9: 1111-1147.

13. Keynes, M, J. (1936): La théorie générale de l'emploi, l'intérêt et la monnaie. [trad.] Jean- de Largentaye. Payot. Paris, pp. 1-181. Vol. IV, V , VI.

14. Lucas E, R. (1967): Optimal Investment Policy and the Flexible Accelerator, International Economic Review, 8: 78-85.

15. Mohsen, A, S. (2015): Effects of Trade Openness And Economic Growth on the Private Sector Investment in Syria. Journal of Applied Management and Investments 4.3 : 168-176.

16. Molapo, S. and Damane, M. (2015): Determinants Of Private Investment in Lesotho, European Scientific Journal, 11: 473-491.

17. Mutenyo, J., Asmah, E and Kalio, A. (2010): Does Foreign Direct Investment Crowd-out Domestic Private Investment in Sub-Saharan Africa?, The African Finance Journal, 12: 27-51.

18. Naa-Idar, F., Tutu D, A. and Frimpong, M, J. (2012): A Time Series Analysis of Determinants of Private Investment in Ghana (19602010), Journal of Economics and Sustainable Development, 3: 23-33

19. Nainggolan, P., Ramli R., Daulay, M. and Rujiman, R. (2014): An Analysis of Determinant on Private Investment in North Sumatra Province, Indonesia. Journal of Management Research, 7:38-57.

20. Narayan, P, K. (2005): the saving and investment nexus for China: evidence from cointegration tests, Applied Economics, 37, 19791990. 
21. Nelson, C. and Plosser, C, I. (1982): Trends and random walks in macroeconomic time series, Journal of Monetary Economics, 10: 132-162.

22. Oteng-Abayie, E. and Frimpong, J. (2006): Bounds Testing Approach to Cointegration: An Examination of Foreign Direct InvestmentTrade and Growth Relationship, American Journal of Applied Sciences, 3: 2079-2085.

23. Pesaran, M, H., Shin, Y. and Smith, R, J. (2001): Bounds testing approaches to the analysis of level relationships, Journal of Applied Econometrics, 16: 289-326.

24. Tobin, J. (1969): A General Equilibrium Approach To Monetary Theory, Journal of Money, Credit and Banking, 1: 15-29.

25. Touna M., Dia, K, B., Ouedraogo, J. and Zeufack, A. (2002): Ajustement structurel et investissement privé en Afrique: les cas du Burkina Faso, du Cameroun et de la Côte d'Ivoire. Secrétariat d'Appui Institutionnel à la Recherche Economique en Afrique (SISERA), 2002.

26. Treadway, B, A. (1974): The globally optimal flexible accelerator, Journal of Economic Theory , 7: 17-39.

27. Waheed, A. (2015): Determinants of Domestic Private Investment: Test of Alternative Hypotheses for Pakistan, International Journal of Research in Business and Social Science, 4: 35-43. 